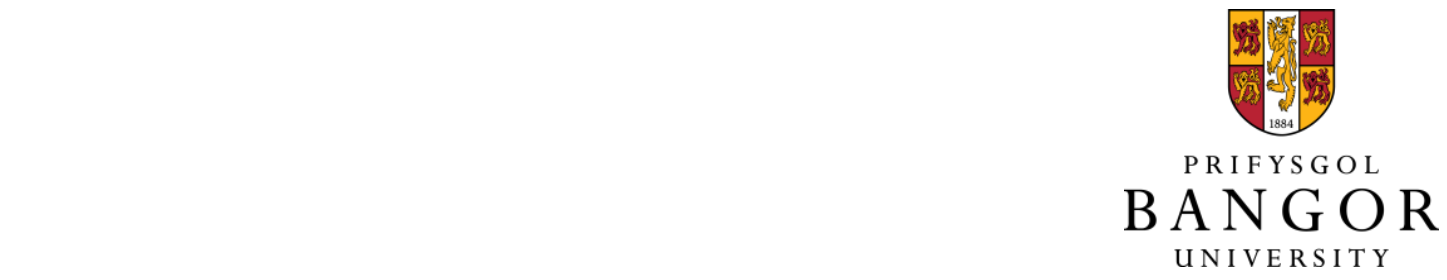

Realising the Olympic dream: vision, support and challenge

Arthur, C.A.; Hardy, L.J.; Woodman, Tim

\title{
Reflective Practice
}

DOI:

$10.1080 / 14623943.2012 .670112$

Published: 03/04/2012

Peer reviewed version

Cyswllt i'r cyhoeddiad / Link to publication

Dyfyniad o'r fersiwn a gyhoeddwyd / Citation for published version (APA):

Arthur, C. A., Hardy, L. J., \& Woodman, T. (2012). Realising the Olympic dream: vision, support and challenge. Reflective Practice, 13(3), 399-406.

https://doi.org/10.1080/14623943.2012.670112

\section{Hawliau Cyffredinol / General rights}

Copyright and moral rights for the publications made accessible in the public portal are retained by the authors and/or other copyright owners and it is a condition of accessing publications that users recognise and abide by the legal requirements associated with these rights.

- Users may download and print one copy of any publication from the public portal for the purpose of private study or research.

- You may not further distribute the material or use it for any profit-making activity or commercial gain

- You may freely distribute the URL identifying the publication in the public portal ?

\section{Take down policy}

This is an Accepted Manuscript of an article published by Taylor \& Francis in Reflective Practice on 3rd of April 2012 available online: http://www.tandfonline.com/doi/abs/10.1080/14623943.2012.670112

\section{Take down policy}

If you believe that this document breaches copyright please contact us providing details, and we will remove access to the work immediately and investigate your claim. 
Article accepted in its current form in Reflective Practice:

Arthur, C., Hardy, L., \& Woodman, T. (2012). Realising the Olympic dream: vision, support and challenge. Reflective Practice, 13, 399-406. doi: 10.1080/14623943.2012.670112 


\section{Realising the Olympic Dream: Vision, Support and Challenge}

Arthur, C. A., Hardy, L., \& Woodman, T.

Institute for the Psychology of Elite Performance

The sporting arena is replete with examples and anecdotes of inspirational coaches that have led teams to success, often in the face of adversity and against seemingly better opponents. Indeed, the influence of the coach is summarised nicely by Dan Britton talking about the legendary basketball Coach John Wooden: "His purpose in coaching was to instil greatness in others. He was committed to teaching, inspiring and motivating people, and he empowered his players to do great things" (p. 13). It is therefore surprising that the models of leadership and coaching in sport are either devoid of the notion of inspiration or only give it a passing mention; we still know very little about precisely why great coaches are great and how in turn they motivate their athletes to achieve Olympic greatness. For example, the sport coaching models developed by Challadurai and colleagues; Smith, Smoll and colleagues; Horn and colleagues; and Côté and colleagues have all provided an insight into the effects of coach behaviours, some processes and mechanisms by which these behaviours exert their influence and the moderating effects of situation, context, and personality. However, there is very little mention of the inspirational effects of great coaches in these theories and models. The purpose of this article is not to provide a review of the sport coaching models (for reviews, see Chelladurai, 1990, 1993, 2007; Chelladurai \& Riemer, 1998; Riemer, 2007; Smith \& Smoll, 2007), rather we will delineate a new model of inspirational coaching based on the principles of vision, support, and challenge.

Underpinned by transformational leadership theory (Bass, 1985) the meta-cognitive model of vision, support, and challenge was first developed by Hardy and Arthur in a 
military context (e.g., Arthur, 2008; Arthur \& Hardy, 2011; Arthur, Hardy, \& Wagstaff, 2010; Hardy \& Arthur, 2006, 2008; Hardy, Arthur, Jones, Shariff, Munnoch, \& Isaacs, 2010; Hardy, Shariff, Munnoch, \& Allsopp, 2004). The model posits that great coaches inspire their athletes by: (a) creating an inspirational vision of the future; (b) providing the necessary support to achieve the vision; and (c) providing the challenge to achieve the vision. The underlying proposition is that the vision provides meaning and direction for athletes' effort. That is, the vision serves as the beacon towards which all the sweat, pain and sacrifice is directed on the path to Olympic success. The premise that underpins the vision, support and challenge model is that athletes can achieve their Olympic dreams provided they are truly inspired to do so; this is because all other things being equal the person who is motivated to practice longer and train harder will ultimately be the best.

An important aspect of the vision, support, and challenge model is that it makes a distinction between what the coach does (i.e., coach behaviours) and the consequences of these coach behaviours (i.e., athlete's meta-cognitions) in the same model. That is, transformational leadership is what the coach does and athlete's perceptions of vision, support, and challenge are a direct consequence of coach behaviours. In the following article we firstly define the vision, support, and challenge constructs in our model, we then describe the impact that vision, support and challenge will have, and lastly we very briefly identify some key coach behaviours that we theorize will predict athlete's perceptions of vision, support, and challenge.

Vision

Primarily based on the charismatic and transformational leadership literatures, vision is defined as the extent to which athletes have an inspirational and meaningful future image of themselves in their sport. Whilst vision has occupied a central role in leadership theories 
from organizational psychology (e.g., Bass, 1985; Berlew, 1974; Conger \& Kanungo, 1988; Kim, Dansereau, \& Kim, 2002; Nanus, 1992) it is only recently emerging in the sport psychology literature. For example, Vallee and Bloom (2005) identified vision as one of the four higher-order themes that the expert coaches identified in their study. This finding has been replicated in other qualitative designs with vision being identified as a key component of success (e.g., Bucci, Bloom, Loughead, \& Jeffrey, 2012; Fletcher \& Arnold, 2011). Furthermore, empirical evidence is also beginning to emerge from the sport transformational leadership literature where inspirational motivation has been shown to predict extra effort and group cohesion (e.g., Arthur, Woodman, Ong, Hardy, \& Ntoumanis, 2011; Callow, Smith, Hardy, Arthur, \& Hardy, 2009). The coach is thought to play a fundamental role in inspiring athletes by imparting a positive vision of the future. The strength of the athlete's vision will then be a key determinant of their motivation to work and train hard for the Olympic Games.

It is hypothesized that the transformational leader behaviours of inspirational motivation and fostering acceptance of group goals will predict vision. This is subtly different from the military model of vision, support and challenge; in the military model we hypothesize that appropriate role modelling will predict vision. This is because in the military context the follower's vision are likely to be formulated around their direct leader because their leader is normally at the next stage of leadership in the organization, hence the follower is likely to be promoted into that leadership role. However, in the sport context the coach is less likely to serve as the future image of the athlete. Consequently, role modelling is not theorized to predict vision in the sport model.

\section{Support}

Athletes need support in order to achieve their vision and to believe that the vision is attainable. A brief review of the social support literature (e.g., Blazer, 1982; Cohen \& Wills, 
1985; House, 1971; Rafferty \& Griffin, 2006; Rees \& Hardy, 2000; Rees \& Hardy, 2004; Rees, Hardy, \& Evans, 2007; Sandler \& Berrera, 1984; Sarason, Sarason, \& Pierce, 1990) suggests that support is multidimensional in nature. The precise number and nature of the sub-dimensions is the subject of some debate (see, for example, Cutrona \& Russell, 1990; Rees \& Hardy, 2004; Rees et al., 2007) but evidence suggests that support includes emotional, esteem, informational, and tangible aspects (Cutrona \& Russell, 1990; Rees \& Hardy, 2004). Another important consideration born out of the social support literature is the notion of received and perceived availability of support. That is, in order to capture the full spectrum of social support one needs to measure both received and perceived availability of support. Based on the literature, the definition of support is: the extent to which emotional, esteem, informational, and tangible support is provided or is perceived as being available when needed.

It is proposed that perceptions of support will help athletes to believe that their vision of Olympic success is achievable and that perceptions of support will contribute to athletes' feeling valued and important. The relationship between support and job satisfaction is described within the social exchange theory framework (e.g., Blau, 1964; Gouldner, 1960). Social exchange theory suggests that people will respond positively to favourable treatment; that is, perceived favourable treatment (e.g., perceptions of support) will be reciprocated with positive affective outcomes (c.f. Gouldner, 1960). In a related vein organizational support theory (Eisenberger, Huntington, Hutchison, \& Sowa, 1986; Shore \& Shore, 1995) posits that the extent to which employees' socio-emotional needs are met will impact global beliefs that the organization values their contributions and cares about their well-being. Supporting the above theoretical links a meta-analysis (Rhoades \& Eisenberger, 2002) found a strong positive relationship between perceived support and job satisfaction in 21 independent samples. 
It is proposed that the leader behaviours of individual consideration, inspirational motivation, and appropriate role modelling will load onto the support component of the model. That is, the more coaches display these behaviours the more supported their athletes will feel.

\section{Challenge}

The notion of challenge has received considerably less research attention. A notable exception to this is the challenge and hindrance stressor differentiation literature (see LePine, LePine, \& Jackson, 2004; Podsakoff, LePine, \& LePine, 2007). This theoretical perspective posits that there are two different types of stress in the workplace: hindrance stress and challenge stress. Hindrance stress includes role ambiguity, role conflict, and hassles that are negatively related to performance (Beehr, Jex, Stacy, \& Murray, 2000; Fox, Spector, \& Mills, 2001; LePine et al., 2004; Podsakoff et al., 2007; Villanova, 1996; Woodman \& Hardy, 2001). Challenge stress includes work demands and workload, which are positively related to performance (Beehr et al., 2000; Beehr, Walsh, \& Taber, 1976; LePine et al., 2004; Podsakoff et al., 2007). It is the challenge component of the hindrance-challenge stress model that is of particular salience to the vision, support, and challenge model. Podsakoff et al. state that leaders who have high performance expectations of their followers and who set goals that stretch their followers will challenge their followers by increasing the magnitude of the discrepancy between a follower's current state and a future desired state. In Olympic terms, the gap between an athlete's current performance and the performance needed for Olympic success will be clearer to the athlete if the coach emphasizes the Olympic expectations with ever more challenging goals. Consequently, the definition of challenge is: an understanding of what needs to be done in order to achieve goals and the gap between current state and a future desired state, with the implicit assumption that the larger the discrepancy the more challenged followers are. 
Whilst the positive effects of challenge might not be as intuitively obvious as the positive impact of vision and support there are some literatures that exhort the positive effects of challenge. For example, Seyle (1978) proposed that humans engaging in stressful and challenging activities often express enjoyment, even euphoria; McCall, Lombardo, and Morrison (1988) suggested that employees thrive when they have challenging job demands; and Campion and McClelland (1991) suggested that challenging job designs are associated with higher levels of satisfaction and involvement. Furthermore, several studies have reported a positive relationship between job challenges and affective outcomes such as satisfaction (e.g., Beehr, Glaser, Canali, \& Wallwey, 2001; Dwyer \& Ganster, 1991; Cavanaugh, Boswell, Roehling, \& Boudreau, 2000). Consequently, there is good reason to believe that challenge will motivate athletes to train harder toward their Olympic aspirations.

It is proposed that the transformational leader behaviours of high performance expectations and intellectual stimulation will predict athlete's perception of challenge. In other words, the more the coach displays these behaviours the greater the perceptions of challenge their athletes will have.

\section{Summary}

Olympic greatness will be achieved by the coach instilling a combination of vision, support, and challenge in their athletes. The coach is at the centre of this process and will be a determining factor in creating the vision and shaping the athlete's perceptions of challenge and support. Clearly, athlete and context play a significant role. For example, athlete optimism may mediate or moderate the likelihood of athletes adopting the vision; and narcissism may impact the content of the vision to reflect some of the core personality factors associated with narcissism (e.g., personal glory). Equally, the support and the level of challenge may need to be adjusted for those athletes lower in self-esteem. The relative 
quantity and quality of support and challenge will also likely have an impact. For example, very high levels of challenge accompanied with very little support will increase the likelihood of athlete burn-out and withdrawal from sport. Conversely, high levels of support accompanied with low levels of challenge will likely lead to de-motivation because of boredom.

Most athletes train for the Olympic Games with dreams of Olympic glory. Coaches who can provide the right balance of vision, support, and challenge will inspire their athletes to realize that dream and achieve Olympic greatness.

Figure 1.

Vision, Support, and Challenge Model

\section{What the Coach Does}
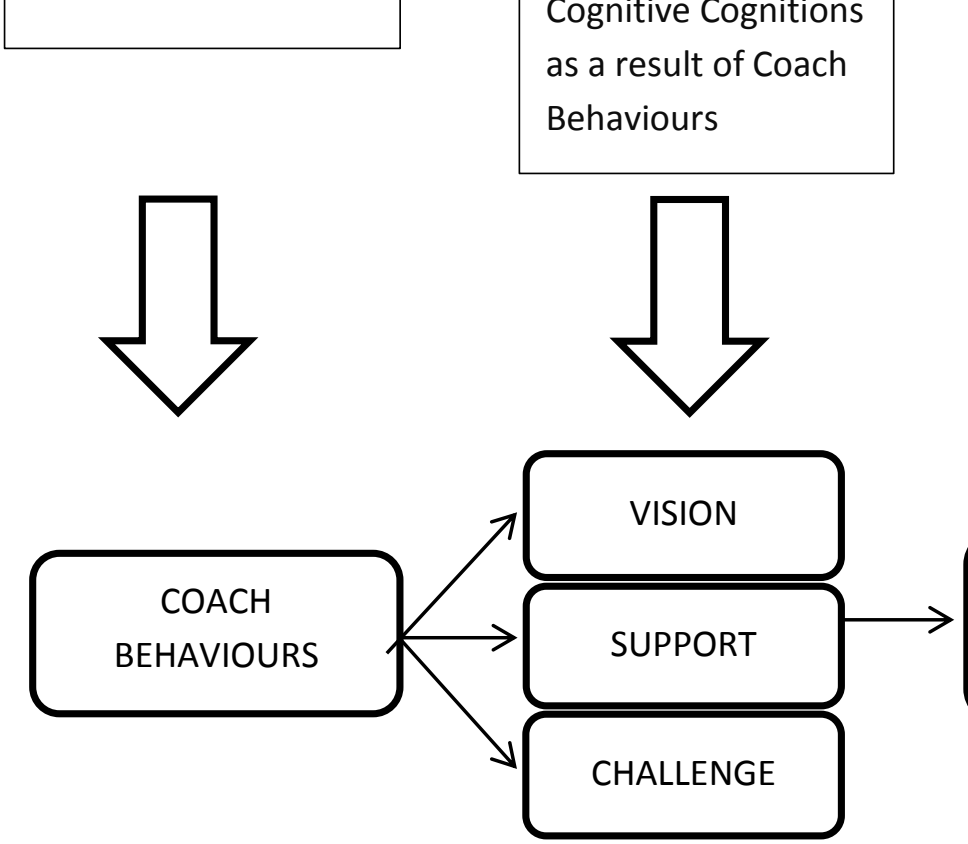

Athlete Meta-

Cognitive Cognitions as a result of Coach

Behaviours
Outcomes of the Meta-Cognitive Cognitions

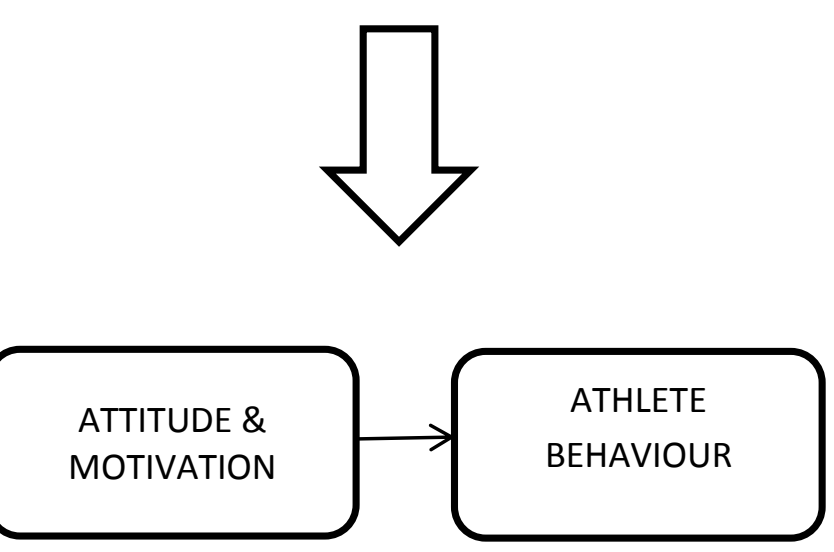




\section{References}

Arthur, C. A. (2008). Transformational leadership in Infantry recruit training in the British Army. PhD, Bangor University.

Arthur, C. A., \& Hardy, L. (2008). Vision, support, and challenge model of transformational leadership, Verbal Presentation, European College of Sports Science, Estoril, Portugal.

Arthur, C. A., Hardy L., \& Wagstaff, C. (2010). Report on study into values based leadership, transactional leadership, and coaching on the internalisation of the core values of the British army, attitude and performance in phase 1 Army training. Institute for the Psychology of Elite Performance, Bangor University, Wales.

Arthur, C.A., \& Hardy, L. (2011). Vision support and challenge: Developing a measure in the military. Verbal Presentation at the Association for Applied Sport Psychology Conference, Hawaii, USA.

Arthur, C. A., Woodman, T., Ong, C. W., Hardy, L., \& Ntoumanis, N. (2011). The role of athlete narcissism in moderating the relationship between coaches transformational leader behaviors and athlete motivation. Journal of Sport and Exercise Psychology, 33, 3-19.

Bass, B. M. (1985). Leadership and performance beyond expectations. New York: Free Press.

Beehr, T. A., Glaser, K. M., Canali, K. G., \& Wallwey, D. A. (2001). Back to basics: Reexamination of demand-control theory of occupational stress. Work and Stress, 15 , 115-130. 
Beehr, T. A., Jex, S. M., Stacy, B. A., \& Murray, M. A. (2000). Work stressor and coworker support as predictors of individual strain and job performance. Journal of Organizational Behavior, 21, 391-405.

Beehr, T. A., Walsh, J. T., \& Taber, T. D. (1976). Relationships of stress to individually and organizationally valued states: Higher order needs as a moderator. Journal of Applied Psychology, 61, 35-40.

Berlew, D. E. (1974). Leadership and organizational excitement. California Management Review, 17, 21-30.

Blau, P. M. (1964). Exchange and Power in Social Life. New York: John Wiley \& Sons.

Blau, P. M. (1964). Exchange and Power in Social Life. New York: John Wiley \& Sons.

Blazer, D. (1982). Social support and mortality in an elderly community population. American Journal of Epidemiology, 115, 684-694.

Bower, D. J., Diehr, S., Mrzinski, J. A., \& Simpson, D. E. (1998). Support-challenge-vision: A model for faculty mentoring. Medical Teacher, 20, 595-597.

Bryman, A. (1992). Charisma and leadership in organizations. London: Sage.

Bucci, J., Bloom, G. A., Loughead, T. M., \& Carron, J. G. (2012). Ice hockey coaches perceptions of athlete leadership. Journal of Applied Psychology.

Callow, N., Smith, M., Hardy, L., Arthur, C.A., \& Hardy, J. (2009). Measurement of transformational leadership and its relationship with team cohesion and performance level. Journal of Applied Sport Psychology, 21, 395-412. 
Campion, M. A., \& McClelland, C. L. (1991). Interdisciplinary examination of the costs and benefits of enlarged jobs: A job design quasi-experiment. Journal of Applied Psychology, 76, 186-198.

Cavanaugh, M. A., Boswell, W. R., Roehling, M. Z., \& Boudreau, J. W. (2000). An empirical examination of self-report work stress among U.S. managers. Journal of Applied Psychology, 85, 65-74.

Chelladurai, P. \& Riemer, H. (1998). Measurement of leadership in sport. In J. L. Duda (Ed.) Advances in sport and exercise psychology measurement (pp. 227-253). Morgantown, W V: Fitness Information technology.

Chelladurai, P. (1990). Leadership in sports: A review. International Journal of Sports Psychology, 21, 328-354.

Chelladurai, P. (2007). Leadership in Sports. In G. Tenenbaum, \& R. C. Gould ( $3^{\text {rd }}$ Ed.) Hanbook of Sport Psychology, (pp. 113-133). John Wiley \& Sons, Inc., Hoboken: New Jersey.

Cohen, S., \& Wills, T. A. (1985). Stress, social support, and the buffering hypothesis, Psychological Bulletin, 98(2), 310-357.

Conger, J. A., \& Kanungo, R. N. (1988). Charismatic leadership: The elusive factor in organizational effectiveness. San Francisco: Jossey-Bass.

Cutrona, C. E., \& Russell, D. W. (1990). Type of social support and specific stress: Toward a theory of optimal matching. In B. R. Sarason, I. G., Sarason, \& G. R.. Pierce (Eds.), Social support: An international view (pp. 319-366). New York: Wiley. 
Dwyer, D. J., \& Ganster, D. C. (1991). The effects of job demands and control on employee attendance and satisfaction. Journal of Organizational Behavior, 12, 595-608.

Eisenberger, R., Huntington, R., Hutchison, S., \& Sowa, D. (1986). Perceived organizational support. Journal of Applied Psychology, 71, 500-507.

Fletcher, D., \& Arnold, R. S. (2011). A qualitative study of performance leadership and management in elite sport. Journal of Applied Sport Psychology, 23, 223-242.

Gouldner, A. W. (1960). The norm of reciprocity: A preliminary statement. American Social Review, 25, 161-178.

Hardy L., \& Arthur, C. A. (2008). A study into the section commanders course at the Infantry Battle School Brecon. Institute for the Psychology of Elite Performance, Bangor University, Wales

Hardy, L., \& Arthur, C. A. (2006). Final report on Study into the Infantry Training Centre Coaching and Leadership Initiative, Institute for the Psychology of Elite Performance, University of Wales, Bangor.

Hardy, L., Arthur, C. A., Jones, G., Shariff, A., Munnoch, K., Isaacs, I., \& Allsopp, A. J. (2010). The relationship between transformational leadership behaviours, psychological, and training outcomes in elite military recruits. The Leadership Quarterly, 21, 20-32.

Hardy, L., Shariff, A., Munnoch, K., \& Allsopp, A. (2004). Can Leadership development positively influence the psychological environment military recruit training? An interim report evaluation of the Royal Marine Coaching Advisory Team Leadership 
Innovative. INM Report 2004.005. The Institute of Naval Medicine, Alverstoke, Hants.

House, R. J. (1971). A path-goal theory of leadership effectiveness, Administrative Science Quarterly, 16, 321-339.

Kim, K., Dansereau, F., \& Kim, I. (2002). Extending the concept of charismatic leadership: An illustration using Bass's (1990) categories. In B. J. Avolio \& F. J. Yammarino (Eds.), Transformational and Charismatic Leadership: The Road Ahead. (pp. 35-66). Oxford, UK: JA/Elsevier.

McCall, M. W., Jr., Lombardo, M. M., \& Morrison, A. M. (1988). The lessons of experience: How successful executives develop on the job. Lexington, MA: Lexington Books.

Nanus, B. (1992). Visionary Leadership. San Francisco: Jossey-Bass.

Podsakoff, N. P., LePine, J. A., \& LePine, M. A. (2007). Differential challenge stressorhindrance stressor relationships with job turnover attitudes, turnover intentions, turnover, and withdrawal behavior: A meta-analyses. Journal of Applied Psychology, 92, 438-454.

Podsakoff, P. Fox, S., Spector, P. E., \& Mills, D. (2001). Counterproductive work behavior (CWB) in response to job stressor and organizational justice: Some mediator and moderator tests for autonomy and emotions. Journal of Vocational Behavior, 59, 291309.

Rees, T., \& Hardy, L. (2000). An investigation of the social support experiences of high-level sports performers, The Sports Psychologist, 14, 327-347. 
Rees, T., \& Hardy, L. (2004). Matching social support with stressors: Effects on factors underlying performance in tennis, Psychology of Sport and Exercise, 5, 319-337.

Rees, T., Hardy, L., \& Evans, L. (2007). Construct validity of the social support survey in sport, Psychology of Sport and Exercise, 8, 355-368.

Riemer, H. A. (2007). Multidimensional model of coach leadership. In S. Jowett \& D. Lavallee (Eds.) Social psychology in sport (pp. 57 -74). Human Kinetics Inc.

Sandler, I. N., \& Berrera, M., Jr. (1984). Toward a multimethod approach to assessing the effects of social support. American Journal of Community Psychology, 12, 37-57.

Sarason, B. R., Sarason, I. G., \& Pierce, G. R. (1990). Traditional views of social support and their impact on assessment. In B. R. Sarason, I. G. Sarason, \& G. R. Pierce (Eds.), Social support; An international view (pp-9-25). New York: Wiley.

Seyle, H. (1978). The stress of life. New York: McGraw-Hill.

Smith , R. E., \& Smoll, F. L. (2007). Social-cognitive approach to coaching behaviors. In S. Jowett \& D. Lavallee (Eds.) Social psychology in sport (pp. 75-90). Human Kinetics Inc.

Smoll, F. L., \& SmithRhoades, L., \& Eisenberger, R. (2002). Perceived organizational support: A review of the literature. Journal of Applied Psychology, 87, 698714LePine, LePine, \& Jackson, 2004;

Vallee, C. N., \& Bloom, G. A. (2005). Building a successful university program: Key and common elements of expert coaches. Journal of Applied Sport Psychology, 17, 179196. 
Villanova, P. (1996). Productive validity of situational constraints in general versus specific performance domains. Journal of Applied Psychology, 81, 532-547

Yukl, G. J. (1998). Leadership in organizations. Englewood Cliffs, NJ: Prentice-Hall. 